\title{
Study of Genetic Variability and Character Association for Water Use Efficiency (WUE) and Yield Related Traits Advance Breeding Lines of Groundnut (Arachis hypogea L.)
}

\author{
Syed Sab", J. Shanthala, D. L. Savithramma and M. R. Bhavya
}

Department of Genetics and Plant Breeding, University of Agricultural Sciences, G.K.V.K., Bengaluru - 560065 (Karnataka), India

*Corresponding author

\begin{abstract}
A B S T R A C T

\begin{tabular}{|c|}
\hline Keywords \\
\hline $\begin{array}{l}\text { Arachis hypogaea, } \\
\text { genetic parameters, } \\
\text { phenotypic correlation, } \\
\text { heritability, genetic } \\
\text { advance }\end{array}$ \\
\hline Article Info \\
\hline $\begin{array}{l}\text { Accepted: } \\
24 \text { May } 2018 \\
\text { Available Online: } \\
\text { 10 June } 2018\end{array}$ \\
\hline
\end{tabular}

Introduction

Groundnut (Arachis hypogaea L.) is one of the most important oilseed crops of the world that belongs to the family: Fabaceae and sub family Papilionoidae with a chromosome number of $2 \mathrm{n}=40$. Extreme climatic conditions, of which drought is one of the most important abiotic stress that poses a major threat to groundnut production, Since over two third of groundnut area in India is grown under rainfed conditions where frequent dry spells is a major limiting factor among the abiotic factors for productivity as compared to other countries (Birthal et al.,
\end{abstract}

Genetic variation and association among nine characters were studied in 34 advanced breeding lines of groundnut for WUE and yield related traits during summer 2015. Higher estimates of PCV and GCV were recorded for Pod Yield per plant followed by Kernel Yield per plant and Pods per plant indicating the presence of sufficient variability between advanced breeding lines. High heritability with high GAM was observed for yield related traits and SLA; high heritability and low GAM for SCMR, days to first flowering and primary branches per plant indicated the involvement of additive and non-additive gene action. SCMR and yield related traits had strong positive association with pod yield per plant where as SLA exhibited strong negative association with pod yield per plant. Sixteen vance breeding lines superior to parent and checks TMV-2 and KCG-2 in their mean performance having higher pod yield and pods per plant were selected out of eight crosses. 
Efficiency is one such important trait which is correlated with Specific Leaf Area (SLA), Soil Plant Analysis development (SPAD) Chlorophyll Meter Reading (SCMR) and Carbon Isotopic Discrimination $\left(\Delta^{13} \mathrm{C}\right)$ (Shashidhar, 2002). Nageswara Rao et al., (2001) and Sheshashayee et al., (2006) reported positive correlations of SCMR and negative correlation SLA with WUE in groundnut, suggesting that SLA, SCMR can be used as a surrogate trait to measure WUE in groundnut. The SCMR has been used effectively to determine leaf nitrogen content non-destructively in a number of crops including groundnut (Nageswara Rao et al., 2001). Nageswara Rao et al., (2001) reported significant and high negative interrelationship among SLA and SCMR.

In order improve pod yield of groundnut, the plant breeder must have knowledge on the type of gene action in different biometrical traits which contribute for enhanced yield. The plant breeder must consider genetic variability for planning suitable measures for the crop improvement.

This necessitates a thorough knowledge of variability owing to genetic factors, actual heritable genetic variation in the progeny and the genetic advance that can be achieved through selection. The present study has been undertaken to determine the estimates of variability, heritability and genetic advance for yield and physiological traits related to Water Use Efficiency in Thirty four advance breeding lines derived from eight different crosses of groundnut.

\section{Materials and Methods}

Thirty four advance breeding lines were selected based on their yield performance, WUE and disease reaction during kharif2014 from eight crosses viz., NRCG12473 × ICG12370, NRCG12274 × ICG12370,
ICG12370 ×NRCG12473, GKVK-8B $\times$ GPBD-4, GKVK-5 × GPBD-4, ICG $12370 \times$ NRCG12274,GKVK-8B $\times$ KCG-2 and GKVK-5× KCG-2. These lines along with two checks TMV-2 and KCG-2 were evaluated for yield and WUE during summer 2015. Selected advance breeding lines were evaluated in Randomized Complete Block Design with two replications for yield and WUE. Each selected line was grown in different blocks with spacing of $30 \times 15 \mathrm{~cm}$ in the plot size of $2 \times$ 2.1 sq. m. Observations were recorded on 10 plants selected at random for water use efficiency traits viz., days to $50 \%$ flowering, SPAD chlorophyll meter reading at 60 DAS, specific leaf area $\left(\mathrm{cm}^{2} \mathrm{~g}^{-1}\right)$ at 60 DAS, plant height $(\mathrm{cm})$, Primary branches per plant, pods per plant, pod yield per plant (g), kernel yield per plant $(\mathrm{g})$, sound mature kernel percentage (\%) and Shelling (\%).The phenotypic and genotypic coefficients of variation for all the characters were estimated using the formulae of Burton and De Vane (1953) and Heritability, genetic advance were worked out as per the method outlined by Hanson et al., (1956) respectively.

\section{Results and Discussion}

Analysis of variance was carried out for traits related to growth, water use efficiency and yield in selected advance breeding lines of groundnut. Analysis of variance (Table 1) revealed that the mean squares due to genotypes were significant indicating the presence of sufficient amount of variability among the advanced breeding lines for all the traits studied. This was further supported by the fact that range was quite wider for all the characters studied. The magnitude of the genetic variability was indicated by the parameters viz., mean, range, phenotypic and genotypic coefficients of variability, heritability estimates and predicted genetic advance as per cent mean were computed for all the are given in Table 2 . 
Less difference observed between GCV and $\mathrm{PCV}$ indicates the greater role of genetic components and less influence by environment. Highest GCV and PCV was recorded for Pod Yield per plant (25.16 \& 27.13) followed by Kernel Yield per plant (23.10 \&25.59) and Pods per plant (20.74 \&23.00).Hence, individual plant selection can be practiced for the above mentioned characters to get higher yields. Concomitant results were obtained by Dandu et al., (2012), Narasimhulu et al., (2012), Priyadharsini (2012), Anitha (2013), John et al., (2013), Narasimhulu et al., (2013), Mukesh et al., (2014) and Thirumala et al.,(2014); Prabhu et al., (2015 a); Hugar and Savithramma, 2016; Divyadharsini et al., 2017 for pod yield per plant and Kernel Yield per plant, for Pods per plant Dandu et al., (2012), Narasimhulu et al., (2012), Priyadharsini (2012), Anitha (2013), John et al., (2013), Narasimhulu et al., (2013), Mukesh et al., (2014); Kadam et al., 2016; (Rajarathinam et al., 2017); Divyadharsini et al., 2017.

Moderate GCV and PCV were observed for Plant height (16.32 \& 17.11), Primary branches per plant (12.71 \& 17.57) and SLA (15.56 \& 17.63). Similar results have been reported by Nandini et al., 2011; Zaman et al., (2011), Vishnuvardhan et al., (2012) and Mukesh et al., (2014) for plant height and primary branches, for SLA (John et al., 2011; John and Reddy, 2014). Shelling percentage (12.18 \&13.29) also registered moderate GCV and PCV. Similar results were for Shelling percentage by Nandini et al., 2011; John et al., 2011Zaman et al., 2011; John et al., 2013; Hugar and Savithramma, 2016; (Rajarathinam et al., 2017).

The low GCV and PCV was observed for SMK\% (9.51 \& 12.82), SCMR (8.21 \& 9.91) and $50 \%$ flowering (4.72 \& 6.28). Same results were observed by(MakhanLal et al., 2003) for days to fifty per cent flowering and for SCMR
(Nandini et al., 2011); Hugar and Savithramma, 2016, for SMK John et al., 2011; Mukesh et al., (2014); Shridevi et al., (2014); Ashutosh and Prashant et al., (2014); Kadam et al., 2016; Balaraju and Kenchanagoudar, (2016); Divyadharsini et al., 2017. Days to $50 \%$ flowering recorded lower PCV and GCV which is analogous to the results obtained by John and Reddy, 2014; Padmaja et al., 2015; Sabiel et al., 2014; Thirumala, 2014; Nandini et al., 2010; Nandini et al., 2011; Patil et al., 2014 which indicates the presence of narrow genetic variability for this trait (Gupta et al., 2015); Kadam et al., 2016.

Heritability value alone cannot give information on the amount of genetic progress that would result from selection of best individuals. Johnson et al., (1955) pointed that heritability estimates along with genetic gain would be more useful than alone in predicting the effectiveness of selecting the best individuals. Therefore it is necessary to consider the predicted genetic advance along with high heritability estimates as a tool in selection programme for better efficiency in the selection.

High heritability coupled with high genetic advance as percent of mean was registered for the traits viz., Plant height (90.90 \&32.05) followed by Pod Yield per plant (86.02 \& 48.09), shelling percentage (84.00 \& 22.99), Kernel Yield/plant (81.45 \& 42.95), Pods/plant (64.00 \& 31.70) and SLA (77.80 \&28.27). This indicates that these characters are gene action and selection for genetic improvement will be worthwhile and may rapidly contribute yield. Therefore, it was amply clear that these traits were less influenced by the environmental changes and hence improvement in these traits would be more effective through single selection owing to their additive gene effects and with simple phenotypic selection. 
Table.1 Analysis of Variances for growth, pod yield and water use efficiency in 36 advanced breeding lines of Groundnut derived from eight crosses of groundnut during summer 2015

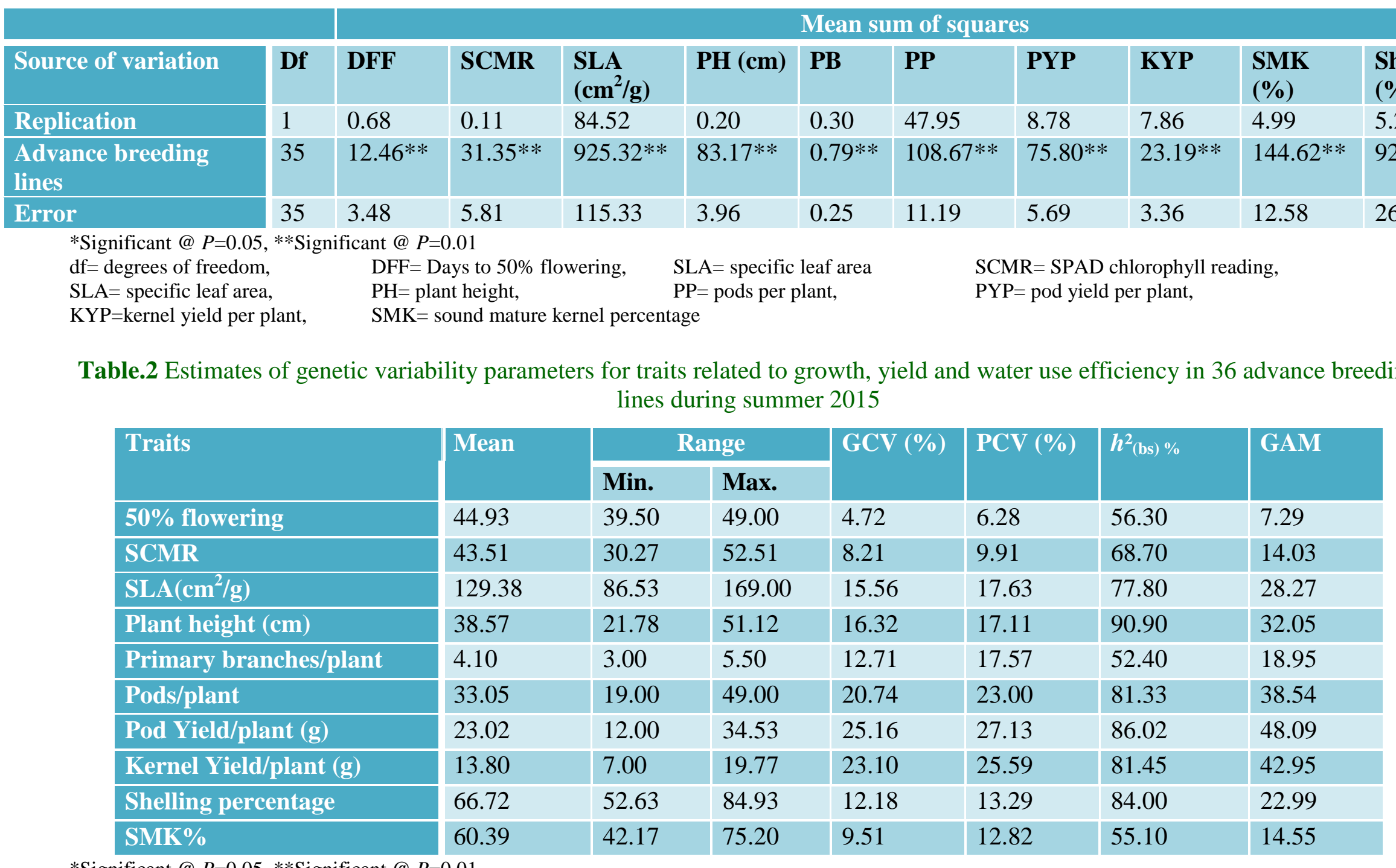

*Significant @ $P=0.05, * *$ Significant @ $P=0.01$ 
Table.3 Phenotypic correlation coefficient for traits related to yield and traits related to WUE in 36 advance breeding lines during 2015

\begin{tabular}{|c|c|c|c|c|c|c|}
\hline Traits & SCMR & SLA & $\begin{array}{l}\text { Pods/ } \\
\text { plant }\end{array}$ & $\begin{array}{c}\text { Kernel } \\
\text { yield/plant }\end{array}$ & $\begin{array}{c}\text { Shelling } \\
(\%)\end{array}$ & $\begin{array}{c}\text { Pod } \\
\text { yield/plant }\end{array}$ \\
\hline SCMR & 1 & $-0.366 *$ & $0.519 * *$ & $0.442 * *$ & $-0.374 *$ & $0.583 * *$ \\
\hline SLA & & 1 & -0.223 & $-0.309 *$ & -0.143 & $-0.234 *$ \\
\hline Pods/plant & & & 1 & $0.847 * *$ & $-0.212 *$ & $0.871 * *$ \\
\hline Kernel yield/plant(g) & & & & 1 & 0.049 & $0.906 * *$ \\
\hline Shelling $(\%)$ & & & & & 1 & $-0.371 *$ \\
\hline Pod yield/plant (g) & & & & & & 1 \\
\hline
\end{tabular}

Table.4 Superior lines selected from 34 advance breeding lines in groundnut

\begin{tabular}{|c|c|c|c|c|c|}
\hline Sl. No. & $\begin{array}{c}\text { Advanced } \\
\text { breeding lines }\end{array}$ & SCMR & SLA & Pods/ plant & $\begin{array}{c}\text { Pod } \\
\text { yield/Plant (g) }\end{array}$ \\
\hline 1 & SS-31 & 44.95 & 110.50 & 42.60 & 35.62 \\
\hline 2 & SS-16 & 42.34 & 143.50 & 47.10 & 34.53 \\
\hline 3 & SS-4 & 41.29 & 118.30 & 49.00 & 32.44 \\
\hline 4 & SS-15 & 44.06 & 169.00 & 44.90 & 31.64 \\
\hline 5 & SS-8 & 43.05 & 127.40 & 40.30 & 31.62 \\
\hline 6 & SS-13 & 48.76 & 127.82 & 39.60 & 31.50 \\
\hline 7 & SS-7 & 41.92 & 147.60 & 39.10 & 29.70 \\
\hline 8 & SS-19 & 40.62 & 130.60 & 35.00 & 28.56 \\
\hline 9 & SS-9 & 41.88 & 86.53 & 38.10 & 28.50 \\
\hline 10 & SS-25 & 42.58 & 130.30 & 37.64 & 28.27 \\
\hline 11 & SS-10 & 42.54 & 110.00 & 40.00 & 27.00 \\
\hline 12 & SS-29 & 43.30 & 148.20 & 29.20 & 26.80 \\
\hline 13 & SS-5 & 45.25 & 112.00 & 33.00 & 26.00 \\
\hline 14 & SS-32 & 43.20 & 109.20 & 36.49 & 25.66 \\
\hline 15 & SS-34 & 43.42 & 122.50 & 39.00 & 25.27 \\
\hline \multirow[t]{2}{*}{16} & SS-1 & 42.50 & 106.10 & 38.00 & 24.00 \\
\hline & Mean & 43.50 & 129.38 & 33.04 & 23.01 \\
\hline Check-1 & KCG-2 & 43.82 & 155.18 & 23.70 & 14.15 \\
\hline \multirow[t]{3}{*}{ Check-2 } & TMV-2 & 43.89 & 141.23 & 30.30 & 24.05 \\
\hline & SE & 1.70 & 7.59 & 3.367 & 3.022 \\
\hline & CV (\%) & 5.53 & 8.30 & 14.40 & 18.57 \\
\hline
\end{tabular}

For plant height, Pod Yield per plant, Kernel Yield/plant, shelling percentage and Pods/plants; similar results were earlier reported by Shinde et al., (2010), John et al., (2013), Narasimhulu et al., (2013), Padmaja et al., (2013), Terkimbi and Terkula (2014)
Ashish et al., (2014), Thirumala et al., (2014) and Prabhu et al., (2015 a); Anusha and Savtramma, 2016; Divyadharsini et al., 2017 Rajarathinam et al., 2017), and for SLA by Nandini, et al., 2011; Savita, et al., 2016. High heritability and moderate genetic 
advance as per cent mean was observed for SCMR (68.70 \& 14.03). Concomitant result was reported by Ramana et al., 2015; Rao, 2016). Moderate heritability and moderate GAM was observed for SMK\% (55.10 \& 14.55) and Primary branches/plant $(52.40 \&$ 18.95). For Days to $50 \%$ flowering moderate heritability and low genetic advance as per cent (56.30 \& 7.29). Similar result for SMK Patil 2015; Rajarathinam et al., 2017, for Primary branches/plant and Days to $50 \%$ flowering John et al., (2013); Patil et al., 2014; Prabhu 2015, Patil 2015, savita et al., 2016.

Moderate to low heritability (broad sense) indicates the greater influence of environment in the expression of these traits and genetic advance can help to predict the extent of genetic improvement that can be achieved for the traits. High heritability coupled with low genetic advance indicates the greater role of non-additive genetic variance like epistatic and dominant interaction factors controlling the inheritance of these traits.

Correlation coefficient helps the breeder in determining relative importance of yield component for indirect selection for yield. Understanding the relationships among yield and yield components is of prime importance for making the best use of these relationships in selection. Association among yield attributing characters and traits related water use efficiency is presented in Table 3.

Pod yield per plant exhibited significant positive correlation with SCMR (0.583), pods per plant (0.871), kernel yield per plant (0.906) and significant negative association with SLA (-0.234), shelling percentage (0.371) Thirumala et al., (2014). Similar result was noticed by Mukhtar et al., (2011), Shoba et al., (2012) for SCMR, pods per plant, kernel yield per plant and for SLA by Nandini et al., (2012). Shelling percentage showed significant negative association with SCMR ($0.374)$, pods per plant $(-0.212)$ and negative association but not significant with SLA (0.143 ) which is in accordance with Nandini et al., (2012). Kernel yield per plant noticed significant positive association with pods per plant (0.442), SCMR (0.847) and significant negative association was observed with SLA (- 0.309). Pods per plant showed significant positive association with SCMR (0.519) and non-significant negative association with SLA (-0.223). SCMR showed significant negative association with SLA (-0.366). Pods per plant showed significant positive association with SCMR and negative non-significant association with SLA. These results are in agreement with Thakur et al., (2013). SCMR showed significant negative association with SLA. Similar results are results were noticed by Songsri et al., (2009), Painwadee et al., (2009), Nandini et al., (2011) and Thakur et al., (2013).

Top Sixteen breeding lines having high pod yield per plant and pods per plant as compare to checks viz., KCG-2 and TMV-2 were selected out of 34 advance breeding lines during summer 2015 (Table 4).

In conclusion, the success of plant breeding programs relies heavily on the existence of genetic variability in breeding for a particular trait. Taken as a whole, high percentage of PCV, GCV, heritability coupled with high GAM were recorded for pod yield per plant, kernel yield per plant, number of pods per plant which indicates the presence of additive gene effect and these traits are expected to respond to selection with greater efficiency. Since SLA scored higher heritability estimates coupled with higher genetic advance as Per cent mean among the surrogate traits studied, it could be used for selecting high Water Use Efficient genotypes compared to SPAD chlorophyll meter reading which scored lower genetic advance. 


\section{References}

Anitha, B.K. 2013. Identification of quantitative trait loci for oil yield and marker assisted backcross for high oleic acid in groundnut (Arachis hypogaea L.). Ph.D. (Ag.) Thesis. Submitted to the Tamil Nadu Agricultural University, Coimbatore.

Ashutosh, K. S. and Prashant, K. R., 2014, Evaluation of groundnut genotypes for yield and quality traits.Ann. Pl. Soil Re., 16(1): 41-44.

Balaraju, M. and Kenchanagoudar, P. V., 2016, Genetic variability for yield and its component traits in interspecific derivatives of groundnut (Arachis hypogaea L.). J. Farm Sci., 29(2): 172176.

Birthal, P. S., Nigam, S. N., Narayanan, A. V., Kareem, and K. A., 2012, Potential economic Benefits from adoption of improved drought tolerant in India. Agric. Economics Res. Revi., 25(1): 114.

Dandu, S. J., Vasanthi, R. P., Reddy, K. R. and Sudhakar, P. 2012, Variability, heritability and genetic advances in F2generation of 15 crosses involving bold-seeded genotypes in groundnut (Arachis hypogaea L.). Int. J. Applied Biol Pharm. Tech., 3(1): 368-372.

Divyadharsini, R., Prabhu, R., Manivannan, N. and Vindhiyavarman, P., 2017, Variability Studies for Quantitative Traits in F3 Generation of Groundnut (Arachis hypogaea

L.). Int.J.Curr.Microbiol.App.Sci (2017) 6(4): 1326-1334

Hugar, A. A. and Savithramma, D. L., 2016, Genetic variability studies for yield and surrogate traits related to water use efficiency in the recombinant inbred line (RIL) population derived from nrcg $12568 \times$ nrcg 12326 of groundnut
(Arachis hypogaea L.). Int. J. Agric. Sci. Res., 5(6): 321-328.

John, K. and Raghava Reddy, P., 2014, Variability, heritability and genetic advances for water use efficiency traits in groundnut (Arachis hypogaea L.). Int. J. Curr. Sci., 13: 1-5.

John, K., Reddy, P. R., Reddy, P. H., Sudhakar, P. and Reddy, N. P. E., 2011, Genetic variability for morphological, physiological, yield and yield traits in $\mathrm{f} 2$ populations of groundnut (Arachis hypogaea L.). Int. J. Applied Biol. Pharm. Techn., 2(4): 463-469.

John, K., Vasanthi, R. P., Sireesha, K. and Giridhara Krishna, T. 2013. Genetic Variability Studies in Different Advanced Breeding Genotypes of Spanish Bunch Groundnut (Arachis hypogaea). Int. J. Applied Bio. and Pharm. Tech., 4(2): 185-187.

Kadam, D. E., Patil, F. B., Bhor, T. J. and Harer, P. N. 2007.Stability for dry pod yield and days to maturity in groundnut genotypes.J. Maharashtra Agric. Uni. 25(3): 322-323.

Kadam. V. K., Chavan B. H., Rajput H. J. and Wakale M. B., 2016, Genetic diversity in Summer Groundnut (Arachis hypogea L.). Int. Res. J. Multidisci. Stud., 2(1): 1-11.

Makhan Lal., Roy, D. and Ojha, O. P., 2003, Genetic variability and selection response for root and other characters in groundnut (Arachis hypogaea L.). Legume Res., 26(2): 128-130.

Mukesh, K.M., Rai, P.K., Kumar, A., Singh, B.A. and Chaurasia, A.K. 2014. Study on genetic variability and seed quality of groundnut (Arachis hypogaea L.) genotypes. International Journal of Emerging Technology and Advanced Engineering 4(6): 818-823.

Mukhtar, A. A., Tanimu, B. S., Ibrahim, I. U., Abubakar and Babaji, B. A., 2011, Correlations and path coefficients 
analysis between pod yield and some quantitative parameters in ground nuts (Arachis hypogaea L.).Int. J. Sci. Nature, 2(4): 799-804.

NageshwaraRao, R. C., Talwar, H. S. and Wright, G. C., 2001, Rapid assessment of specific leaf area and leaf nitrogen in peanut using chlorophyll meter. J.Agron. Crop Sci., 186: 175-182.

Nandini, C. and Savithramma, D.L. (2012). Character association and path analysis in F8 recombinant inbred line population of the cross NRCG $12568 \mathrm{x}$ NRCG 12326 in groundnut (Arachis hypogea L.). Asian J. Bio. Sci., 7(1): 55 $-58$.

Nandini, C., Savithramma D. L. and Naresh Babu, N., 2011, Genetic variability analysis for surrogate traits of water use efficiency in F8 recombinant inbred lines of the cross NRCG $12568 \times$ NRCG 12326 in groundnut (Arachis hypogaea L.). Electronic J. Pl. Bre., 2(4): 555-558.

Narasimhulu, R., Kenchanagoudar, P. V, Gowda, M. V. C. and Sekhar, L., 2013, Genetic variability and correlation studies for selection of multiple disease resistance lines in two crosses of peanut. Bioinfolet., 10(1B): 183-186.

Narasimhulu, R., Kenchanagoudar, P.V. and Gowda, M.V.C. 2012, Study of genetic variability and correlations in selected groundnut genotypes.Int. J. Appl. Bio. Pharm. Techn., 3(1): 355-358.

Padmaja, D., Brahmeswara, R. M. V., Eswari, K. B. and Madhusudhan, R. S., 2013, Genetic variability, heritability for late leaf spot tolerance and productivity traits in a recombinant inbred line population of groundnut (Arachis hypogaea L.). J. Agric. Veter. Sci., 5(1): $36-41$.

Painawadee, M., Jogloy, S., Kesmala, T., Akkasaeng, C., and Pathanothai, A., Identification traits related to drought resistant in Peanut (Arachis hypogaea L.). Asian J. Pl. Sci., 8(2):120- 128.

Patil, A. S., Nandanwar, H. R. and Shah, K., 2014, Estimation of variability parameters for yield and its component traits in groundnut (Arachis hypogaea L.).The Bioscan, 9(2): 633-638.

Patil, S., Shivanna, S., Irappa, B. M. and Shweta, 2015, Estimation of variability parameters for yield and its component traits in groundnut (Arachis hypogaea L.). Int. J.Recent Scientific Res., 6(6): 4568-4570.

Prabhu, R., Manivannan, N., Mothilal, A.and Ibrahim, S. M., 2015, Estimates of genetic variability parameters for yield and yield attributes in groundnut (Arachis hypogaea L.). Int. J. Agri. Environ. Biotechno., 8(3): 551-559.

Priyadharshini, M. 2012. Molecular marker analysis for yield and yield component traits under non stress and drought stress conditions in groundnut (Arachis

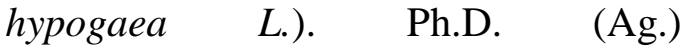
Thesis.Submitted to Tamil Nadu Agricultural University, Coimbatore.

Priyadharshini, M., 2012, Molecular marker analysis for yield and yield component traits under non stress and drought stress conditions in groundnut (Arachis $\begin{array}{lll}\text { hypogaea } & \text { L.).Ph.D. (Ag.) }\end{array}$ Thesis.Submitted to Tamil Nadu Agricultural University, Coimbatore, India.

Rajarathinam, P., Narayana, M., Alagirisamy, M. and Moshin, I. S., 2017, Variability, Correlation and Path Coefficient Analysis in Groundnut (Arachis hypogaea L.).

Ramana, E. V., Vasanthi, R. P., Reddy, K. H., Reddy, B. V. B. and Reddy, B. R., 2015, Studies on genetic variability for yield, yield components and resistance to kalahasti malady in groundnut (Arachis hypogaea L.). 
Rao, V. R., 2016, Genetic variability, correlation and path coefficient analysis under drought in groundnut (Arachis hypogaea L.). Leg. Res., 39 (2): 319322.

Rao, V. T., Venkanna, V., Bhadru, D. and Bharathi, D. 2014. Studies on Variability, Character Association and Path Analysis on Groundnut (Arachis hypogaea L.).Int. J. Pure App. Biosci. 2(2): 194-197.

Savita, S. K., Savithramma, D. L. and Mamata, K., 2016, Genetic variability of water use efficient ril (s) of the cross GKVK $4 \quad X \quad$ NRCG 12473 and identification of elite genotypes in groundnut (Arachis hypogaea L.). Int. J. Agric. Sci. Res., 6 (5): 375-380.

Shashidhar, G., 2002, Screening diverse germplasm lines of groundnut (Arachis hypogaea L.) for genetic variability in water use efficiency and total dry matter based on stable isotopes and RAPD. M.Sc. (Agric.) Thesis submitted to University of Agricultural Sciences, Bangalore.

Sheshshayee, M. S., Bindumadhava, M., Rachaputi, N. R., Prasad, T. G., Udaykumar, M., Wright, G. C. and Nigam, S. N., 2006, Leaf chlorophyll concentration relates to transpiration efficiency in peanut. Ann. Appl. Biol., 148: 7-15.

Shinde, P. P., Khanpara, M. D., Vachhani, J. H., Jivani, L. L. and Kachhadia, V. H.
2010, Genetic variability in Virginia bunch groundnut. Plant Archives 10(2):703-706.

Shoba, D., Manivannan, N. and Vindhiyavarman, P., 2012, Correlation and Path Coefficient Analysis in Groundnut (Arachis hypogaea L.). Madras Agric. J., 99 (1-3): 18-20.

Thakur, S. B., Ghimire, S. K., Shrestha, M, P., Chaudhary, S. M. and Mishra, B., 2013, Variability in groundnut genotypes for tolerance to drought.Nepal. J. Sci and Tech., 14 (1): 41-50.

Thirumala, R. V., Venkanna, V., Bhadru, D. and Bharathi, D., 2014, Studies on variability, character association and path analysis on groundnut (Arachis hypogaea L.). Int. J. Pure. Appl. Biosci., 2(2):194-197.

Vishnuvardhan, K. M., Vasanthi, R. P., Reddy, K. H. P. and Reddy, B.V., 2012, Genetic variability studies for yield attributes and resistance to foliar diseases in groundnut (Arachis hypogaea L.). Int. J. App. Biol. Pharma., Tech., 3: 390-394.

Zaman, M. A., Khatun, M. T., Ullah, M.Z., Moniruzzamn, M. and Alam, K. H., 2011, Genetic variability and path analysis of groundnut (Arachis hypogaea L.). The Agriculturists, 9(1\&2): 29-36.

\section{How to cite this article:}

Syed Sab, J. Shanthala, D. L. Savithramma and Bhavya M. R. 2018. Study of Genetic Variability and Character Association for Water Use Efficiency (WUE) and Yield Related Traits Advance Breeding Lines of Groundnut (Arachis hypogea L.). Int.J.Curr.Microbiol.App.Sci. 7(06): 3149-3157. doi: https://doi.org/10.20546/ijcmas.2018.706.370 